\title{
Conversion in the Process of Assimilation of Loan-Words
}

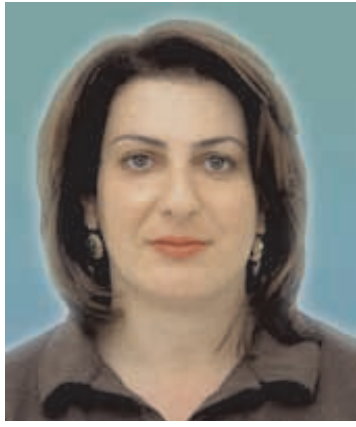

Anahit Galstyan

$\mathrm{C}$ onversion is a prominent matter of debate. It is common knowledge that conversion is one of the most productive ways of creating new words in English, yet not every word can be converted; a great number of cases of conversion can be found in contemporary English, yet not every pair can be treated as a clear case of conversion.

Since it is doubtful in contemporary English whether we are dealing with two meanings of the same word or two words of different origins which have been formally merged as a result of the influence of phonetic development, etymological analysis can provide a solution to the problem of conversion.

We can get a more adequate picture of what conversion is by employing a diachronic approach to the problem in question. It is the latter approach that will enable us to reveal the two-fold nature of conversion which consists in the fact that it can be both the cause and the result of word assimilation.

Conversion sprang into being in the Middle English period and became one of the three main types of word formation (together with affixation and compounding) characteristic of the English language. There are no morphological restrictions on the forms which can undergo conversion, so that compounds, derivatives, acronyms, blends, clipped forms and simple words are all acceptable inputs to the conversion process. The significant productivity of conversion is also displayed by the ability to form new words practically from any part of speech, including prepositions and adverbs. Thus, for example, among French borrowings we come across the adverb encore (a borrowing of the $17^{\text {th }} \mathrm{c}$.), which gained the meaning of a substantive in English -1 . a call (= Please do it again!) which is made by listeners who are pleased with a song or other performance, 2. a song or other performance which is given again because it is asked for. In the same century this word was converted into a verb in English with the following meaning to express approval of (a performer or a performance) by shouting ENCORE. ${ }^{1}$ What we have here is the assimilation of the loan-word encore by means of conversion.

Our investigation of French loan-words comes to prove that cases of noun-verb conversion are of frequent occurrence, such as for example, the French word campagne, which penetrated into English in the $17^{\text {th }}$ century in the expression dans la campagne (a trip into a village). In English the use of this expression was reduced to a single word campagne, which in its turn, was converted into a verb in the following centuries.

Another example was the $16^{\text {th }}$ c. French borrowing bandage with the meaning of strip of material for binding. Soon it was converted into a verb (to bandage in the meaning of 
to tie up or bind round with a bandage) in English. It is clear that the word changed its meaning, grammatical paradigm and syntactic function without any change of wordform. Consequently, we can claim that pairs bandage-n. and bandage-v: campagne- $n$. and campagne $-v$ can be treated as clear cases of conversion.

But the principal source of difficulty lies in the fact that some noun-verb and verbnoun convered pairs are not cases of clear conversion in Modern English. The case in point is the fact that a great number of French (as well as Latin) nouns and verbs were borrowed in the Middle English period when many grammatical and lexical changes took place: reduction of endings and suftixes and simplification of the morphological structure of the word."

The major difficulty with foreign borrowings is that the linguistic structures of different languages may diverge considerably, necessitating in most cases at least some adjustment of loan-words to the native structure of the borrowing language.

One of the most obvious areas in which nativization is called for is phonological structure, for in order to be usable in the borrowing langulage, loans must first and foremost be 'pronounceable's. Sometimes phonological nativization can lead to morphological adaptation, which in its tum, can favour semantic assimilation.

This was the case with the assimilation of French borrowings. Most of them underwent phonological assimilation as soon as they were borrowed. The shift of the stress was very often accompanied by the loss of inflection." After the loss of endings and suffixes, a considerable number of French verbs appeared whose infinitive was not distinct from the corresponding substantives.

Thus, the French verbs of the first class lost their ending eer in English and became identical in form with the corresponding nouns. As a result, the verb and the noun became homonymous but they differed in their paradigm and syntactic structure. For instance, the word circle (the noun (OF cercle-n), and the verb (OF cercler-v.)) was borrowed into English in the $14^{\text {th }} \mathrm{c}$. from Frencts'. In English the verb lost its inflection $-e r$ and became identical with the noun of the same root. In the course of history both words underwent phonological assimilation, but preserved their paradigins and syntactic functions. Consequently, in contemporary English they are treated as a result of conversion. It is worth mentioning that the loan-words of the following centuries underwent similar changes to those occurring in the previous centuries, e.g.

$$
\begin{aligned}
& \text { Fr. contraste }- \text { n., contraster - v. Engl. contrast - n. (16th c.), v. (17th c.) } \\
& \text { Fr. dragon-n., dragommer - v. Engl. dragoon-n., v.(17th c.) } \\
& \text { Fr. influence }-\mathrm{n} \text {., influencer }-\mathrm{v} \text {. Engl, influence }-\mathrm{n} \text {. (14th c.), v. (18th c) }
\end{aligned}
$$

Our investigation of French loan-words shows that alongside 'converted pairs' there are many 'converted triples' in English. For instance, the word close (Latin in origin) penetrated into English in the 13th $\mathrm{c}$. from French in the meaning of a substantive - enclosed place, enclosure. In the following century the corresponding adjective was borrowed in the meaning of - closed, shut up. The most striking point is the fact that the corresponding verb clore $(O F)$ was also borrowed in the 13th $\mathrm{c}$. in its past participle stem 
clos. As a result, the three words had the same word-form, but different paradigms and syntactic functions. In contemporary English this phenomenon is interpreted as a case of conversion when the same word-form has different meanings (that of adjective, noun and verb).

To sum up. we may claim that nativization quite frequently took place through comversion. Due to this type of word-formation, a great number of borrowings underwent grammatical and semantic assimilation.

On the other hand, the discussion of the examples has led us directly to the conclusion that conversion can also be the result of word-assimilation. For such cases of word-formation we suggest the term false conversion.

\section{Notes:}

1 The definitions are taken from Longman Dictionary of Contemporary English, 1978.

2 In theory the growth of conversion is often accounted for by grammatical and lexical changes dutring the Middle English period (Jespersen O. Growth and Structure of the English language. Leipzig, 1938; Smirnitzky A. Lexicology of English. Moscow, 1956). According to this irterpretation, a large number of English verbs and nouns became identical in form after the loss of endings and suffixes. To be more exact, the words in each pair became homonymous: they differed, however, in their grammatical forms (paradigms) and syntactic functions, e.g.
OE Iufit-n., hufian-v.
ME love-n, love-1:
NE love-n, love-v.
OE row-n., rewan-v.
ME raw; row $-n$., row-1:
NE row-n, row-1.

The possibility of using identical words as different parts of speech set up a new pattern of word-building. In Late Middle English this pattern began to be applied by analogy in the creation of new words. It should, however, be noted that this is an area of dispute in the literalure.

3 The most important fact is that once a foreign word has become nativized (or at least not long (hereafter), it is native in every respect and therefore bellaves like a native word, by, for instance, undergoing synchronically productive phonological rules. It will, therefore, from that point onward behave like any other native words also for the purposes of linguistic change.

Since these changes also affected the French borrowings of that period, the assimilation of these words was studied in connection with the many phonetic and lexical changes during Middle English and New English.

4 The tendency towards phonetic reduction in ME contributed to this. This tendency operated in all the subsequent periods of history but was particularly strong in late Middle English.

5 It is worth mentioning that these words are Latin in origin but penetrated into English via French.

6 The stiffix -oon represents the French -on in words with the siress on the final syllable adopted in the $16^{\mathrm{th}}-17^{\mathrm{th}} \mathrm{cc}$., e.g. dragon DRAGOON, chaton SHALLOON, as distinct from the -on of adoptions from AN.(OF), e.g. baron, capon, felon, and of more modern adoptions, e.g. chignon. 


\section{References:}

1. Aitchison J. Language Origin and Evolution. Cambridge, 1996.

2. Algeo J. Problems in the Origins and Development of the English Language. New York, 1982.

3. Barber C.L. The Story of Language. London, Henley and Boston, 1978.

4. Baugh A.C. and Cable T. A History of the English Language. London, 1978.

5. Blake N. The Cambridge History of the English Language. New York, 1992.

6. Bloomfield L. Language. The University of Chicago Press 1935.

7. Encyclopaedia Americana. Egypt, Falsetto, vol. 10, 1978.

8. Jespersen O. Growth and Structure of the English Language. Leipzig. Teubner, 1923.

9. Jespersen O. Language. Its Nature, Development and Origin.London, 1923.

10. Jespersen O. A Modern English Grammar on Historical Principles. London, 6 vol, 1928.

11. Knowles G. A Cultural History of the English Language. London, New York, Sydney, Auckland, 1998.

12. Sinimilzky A. Lexicology of English. Moscow, 1956.

13. Longman Dictionary of Contemporary English. London. Longman. 1978.

14. Mathiew-Rosay J. Dictionnaire Etymologique. Les Nouvelles Editions marabout, Alleur, Belgique,1985.

15. Micro Robert Dictionnaire du Français Primordial. Canada S.C.C. Montréal, tome 1, 2, 1986.

16. A New English Dictionary on Historical Principles. Oxford, 1888-1933.

17. The New Modern Etymological Dictionary of Modern English. London-Glasgow, Collins, 1957.

18. New Webster's Dictionary of the English Language. Subject Publications. New Deihi, 1988.

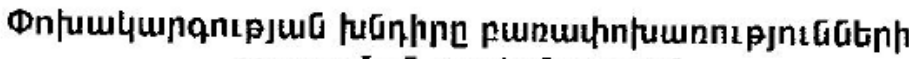 Jnเpugưua qnnophlipugntú}

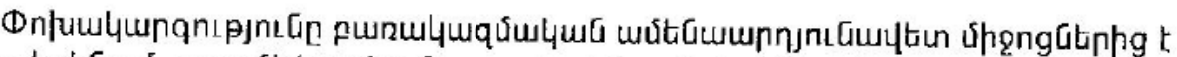

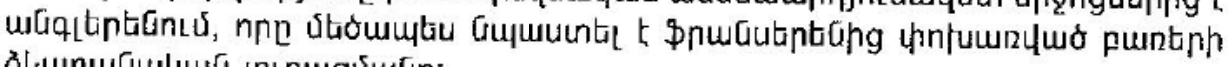

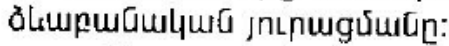

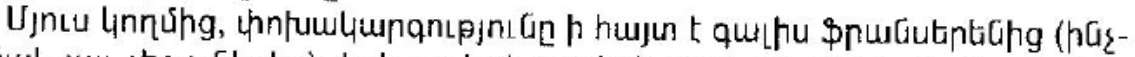

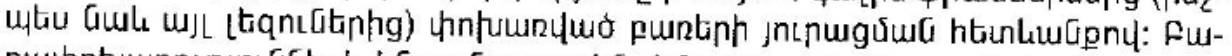

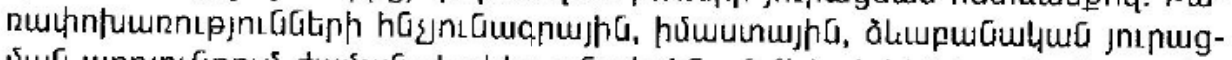

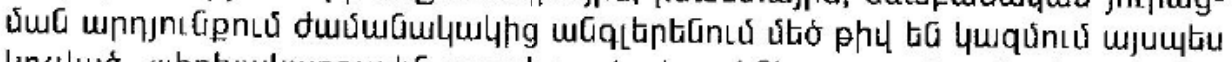

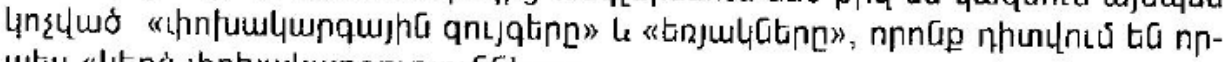

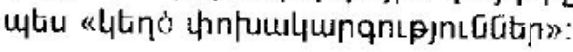

